\title{
Endotherapy for Nonvariceal Upper Gastrointestinal Hemorrhage
}

\author{
Chhagan L. Birda ${ }^{1}$ Antriksh Kumar ${ }^{1}$ Jayanta Samanta ${ }^{1}$ \\ 1Department of Gastroenterology, Postgraduate Institute of \\ Address for correspondence Jayanta Samanta, MD, DM, \\ Medical Education and Research, Chandigarh, India \\ Department of Gastroenterology, Postgraduate Institute of \\ Medical Education and Research, Chandigarh, Sector -12, \\ Chandigarh 160012, India (e-mail: dj_samanta@yahoo.co.in).
}

J Digest Endosc 2021;12:78-92.

\begin{abstract}
Nonvariceal upper gastrointestinal hemorrhage (NVUGIH) is a common $\mathrm{Gl}$ emergency with significant morbidity and mortality. Triaging cases on the basis of patient-related factors, restrictive blood transfusion strategy, and hemodynamic stabilization are key initial steps for the management of patients with NVUGIH. Endoscopy remains a vital step for both diagnosis and definitive management. Multiple studies and guidelines have now defined the optimum timing for performing the endoscopy after hospitalization, to better the outcome. Conventional methods for achieving endoscopic hemostasis, such as injection therapy, contact, and noncontact thermal therapy, and mechanical therapy, such as through-the-scope clips, have reported to have 76 to $90 \%$ efficacy for primary hemostasis. Newer modalities to enhance hemostasis rates have come in vogue. Many of these modalities, such as cap-mounted clips, coagulation forceps, and hemostatic powders have proved to be efficacious in multiple studies. Thus, the newer modalities are recommended not only for management of persistent bleed and recurrent bleed after failed initial hemostasis, using conventional modalities but

Keywords

- upper gastrointestinal bleed

- heat probe

- endoscopic hemostasis

- Helicobacter pylori

- proton pump inhibitors also now being advocated for primary hemostasis. Failure of endotherapy would warrant radiological or surgical intervention. Some newer tools to optimize endotherapy, such as endoscopic Doppler probes, for determining flow in visible or underlying vessels in ulcer bleed are now being evaluated. This review is focused on the technical aspects and efficacy of various endoscopic modalities, both conventional and new. A synopsis of the various studies describing and comparing the modalities have been outlined. Postendoscopic management including Helicobacter pylori therapy and starting of anticoagulants and antiplatelets have also been outlined.
\end{abstract}

\section{Introduction}

Nonvariceal upper gastrointestinal hemorrhage (NVUGIH) is a common GI emergency with an incidence of approximately 60 to $80 / 100,000$ population. ${ }^{1}$ Despite recent advances in endoscopic hemostatic modalities, the mortality rate is 2 to $10 \% .^{1}$ Risk factors for dismal clinical presentation and refractory bleed are advanced age, comorbid illness, history of prior GI bleed, recent surgery, and concomitant use of antithrombotic medications. There are various scoring systems available that incorporate the aforementioned risk factors to triage these patients. ${ }^{2-4}$ Hemodynamic stabilization to maintain adequate tissue perfusion is the key for better patient outcomes. ${ }^{5}$ Endoscopic assessment and adequate published online March 18, 2021
DOI https://doi.org/

$10.1055 / \mathrm{s}-0041-1731962$ ISSN 0976-5042 (c) 2021. Society of Gastrointestinal Endoscopy of India.

This is an open access article published by Thieme under the terms of the Creative Commons Attribution-NonDerivative-NonCommercial-License, permitting copying and reproduction so long as the original work is given appropriate credit. Contents may not be used for commercial purposes, or adapted, remixed, transformed or built upon. (https://creativecommons.org/licenses/by-nc-nd/4.0/).

Thieme Medical and Scientific Publishers Pvt. Ltd. A-12, 2nd Floor, Sector 2, Noida-201301 UP, India 
intervention are the cornerstone for the management of such patients. Various endoscopic modalities are available and have varying efficacies. ${ }^{6}$ Conventional methods of endotherapy include thermal and mechanical methods that achieve hemostasis in majority of patients. Emerging data of the newer modalities, such as over the scope clips (OTSC), hemostatic powders, and monopolar hemostatic forceps suggest their effectiveness both as rescue therapy after failed conventional modalities, as well as primary therapy. ${ }^{7}$ The focus of this review is to discuss the basic management of NVUGIH, as well as to summarize the various endoscopic methods available for the management of NVUGIH, their technical aspects, indications, and overall efficacy ( - Fig. 1).

\section{Epidemiology of Nonvariceal Upper Gastrointestinal Hemorrhage}

The clinical profile of variceal and nonvariceal bleed is different. Patients with variceal bleed are usually middle aged (40-60 years), males, and have a history of significant alcohol intake. These patients also have higher rebleed rate and mortality. Patients with NVUGIH, especially peptic ulcer-related bleed, are usually elderly with associated comorbidities and antecedent history of nonsteroidal anti-inflammatory drugs (NSAIDs), antiplatelet, or anticoagulants use. ${ }^{8-10}$ Epidemiological studies from India have reported a lower mean age and a history of smoking/alcohol use in the majority of cases of upper GI bleed. Compared with the West, history of NSAIDs, antihypertensive, antiplatelet, and anticoagulants use is significantly lower. In India, ruptured esophageal varices is the most common cause of upper gastrointestinal bleed (UGIB) in contrast to the developed countries where peptic ulcer disease (PUD) dominates. ${ }^{9,10}$

In the last two decades, there has been significant advances in the endoscopic and radiological hemostatic techniques with widespread use of proton pump inhibitor (PPI). However, more patients with precomorbid conditions or with antiplatelet/anticoagulant use have complicated the management strategy. ${ }^{11-13}$ Various studies have addressed

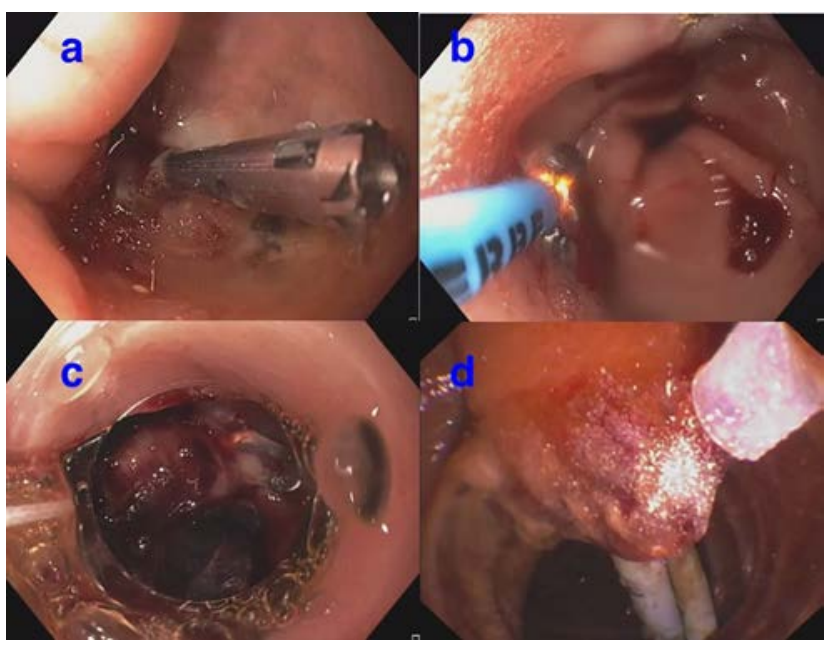

Fig. 1 Endoscopic hemostasis modalities: (A) hemoclip; (B) argon plasma coagulation; (C) over-the-scope clip (OTSC); and (D) hemostatic powder application. the impact of these changes on epidemiology and treatment outcomes. U.S. survey showed a $21 \%$ decline in the hospitalization rate for UGIB with $30 \%$ decline in admission rates for PUD. However, there was no change in the hospitalization rates for variceal bleed. All cause UGIB-related mortality showed a $28 \%$ decline for NVUGIH but not so for variceal bleed. ${ }^{14}$ The mean age, comorbidities, the use of NSAIDs, and antiplatelet have increased over last few decades. ${ }^{15}$

\section{Preendoscopy Management \\ Prognostic Scoring}

A patient presenting with NVUGIH should be triaged after assessing the hemodynamic status of the patient. The commonly used scores are Glasgow Blatchford scale (GBS), Rockall's score, and AIMS-65..$^{2-4}$ GBS is calculated at the time of admission, and a score $>1$ warrants inpatient management. Higher score predicts poorer outcome. ${ }^{2}$ A systematic review reported that the predictive value of GBS was superior to Rockall's and AIMS-65 scores for identifying low risk patients. ${ }^{16}$ In a large prospective study, GBS had the highest accuracy (area under the receiver operating characteristic curve AUROC $=0.86$ ) for predicting need for hospital-based intervention and death. ${ }^{17}$ Supplementary Table S1 (available in the online version) summarizes commonly used scoring systems for upper GI bleed.

\section{Resuscitation}

Initial medical management include fluid resuscitation using crystalloids to maintain adequate tissue perfusion. Restrictive blood transfusion strategy (target of 7-9 g/dL) is preferred in view of lower rebleed rate and mortality except in patients with cardiovascular comorbidities where restrictive transfusion might result in acute coronary events. ${ }^{18}$

\section{Management of Antiplatelet and Anticoagulants}

The risk-benefit ratio for patients receiving antithrombotic agents (antiplatelet/anticoagulants) should be gauged for bleeding versus thrombotic risk, if these agents are stopped. Decision should be taken by a multidisciplinary team including internists, gastroenterologists, cardiologists, and hematologists as higher rates of adverse cardiovascular events and all-cause mortality have been reported in those who stopped antithrombotic agents. ${ }^{19,20}$ Various guidelines recommend to continue aspirin if started as monotherapy or in combination for secondary cardiovascular prevention. ${ }^{21-26}$ Aspirin for primary cardiovascular prophylaxis should be stopped temporarily and if indicated can be resumed within 5 days. ${ }^{25}$ Platelet transfusion can be considered in patients with severe UGI bleed with thrombocytopenia. All the anticoagulants need to be stopped temporarily and can be resumed within 1 week of hemostasis ${ }^{26}$ and can be bridged with heparin in patients with high risk of thromboembolism. Reversal of anticoagulation using vitamin $\mathrm{K}$, prothrombin complex concentrate (PCC), or fresh frozen plasma (FFP), and reversal agents for direct oral anticoagulants (DOAC) should be considered in case of hemodynamic instability. However, the increased risk of thromboembolism and delayed onset of action should be kept in mind if anticoagulant reversal is done. ${ }^{27}$ 


\section{Proton Pump Inhibitors and Other Medications}

High-dose intravenous (IV) PPI (80-mg bolus followed by $8 \mathrm{mg} /$ hour infusion or intermittent bolus PPI) before endoscopy is suggested to downstage stigmata of recent hemorrhage and thereby need for endotherapy. However PPI have no effect on clinically relevant patient outcomes such as blood transfusion requirement, surgery, and 30-day mortality. ${ }^{28}$ In view of lack of significant impact on patient-related outcomes and increased cost, various guidelines have now revised recommendations for routine preendoscopy PPI. In 2018, the Asia-Pacific working group recommended against the indiscriminate use of preendoscopy IV PPIs in hemodynamically stable patients. ${ }^{29}$ Octreotide and antibiotics have no role in NVUGIH but should be started if there is suspicion of variceal bleed. ${ }^{30}$ Tranexamic acid is not indicated in management of upper GI bleed as recent multicenter randomized controlled trial (RCT) showed not only absence of reduction in mortality but also increased risk of thromboembolic events. ${ }^{31}$ Use of prokinetics like erythromycin and metoclopramide 30 to 120 minutes before endoscopy has been shown to facilitate better visualization and successful endotherapy. ${ }^{32}$

\section{Role of Nasogastric Tube and Endotracheal Intubation}

Role of nasogastric (NG) tube in management of patients with GI bleed is controversial. NG tube insertion has no impact on clinical outcome. Moreover, patient discomfort and invasiveness further limit routine insertion..$^{33}$ Routine endotracheal intubation for airway protection is not recommended in view of increased incidence of aspiration, pneumonia, hospital stay, and mortality but should be considered in patients with massive bleed, hemodynamic instability, and altered sensorium. ${ }^{34}$

\section{Endoscopic Management}

In a patient of suspected upper GI bleed, endoscopy plays a key role in the decision-making for further management. It identifies and localizes the source of bleed, plan, and administer treatment and also helps to assess rebleed risk.

\section{When to do?}

The timing to perform UGI endoscopy (UGIE) in acute NVUGIH is classified as emergent (done in $<6$ hours), early (done within 24 hours) and delayed (done after 24 hours). Multiple studies including a recent RCT by Lau et al have tried to ascertain the optimum timing to perform UGIE in such patients. ${ }^{35}$ Majority of the available guidelines recommend an early endoscopy ( $<24$ hours), except for those with GBS of 0 to 1 , where elective endoscopy on an out-patient basis can be considered. ${ }^{25,26}$ However, the timing for patients with hemodynamic instability has not been considered in many of them. To address this issue, the recent AGA guidelines advocates urgent endoscopy ( $<12$ hours) in patients with moderate-to-large volume hematemesis, in-hospital bleed, and those with hemodynamic instability despite adequate resuscitation. ${ }^{26}$

Early esophagogastroduodenoscopy (EGD) is associated with better outcomes in UGIB. Early EGD is associated with a decreased risk of hypovolemia, acute kidney injury, acute respiratory failure, significant reduction in mortality, hospital stay, and lower total hospital cost. ${ }^{36} \mathrm{~A}$ multicenter study from Europe has also reported shorter hospital stay when EGD is performed within 24 hours. ${ }^{37}$ Jeong et al reported significantly higher mortality and longer hospital stay if EGD was delayed for $>24$ hours. $^{38}$

\section{Choice of Instrument}

Therapeutic endoscopes (single or double channel) are preferred since they allow better suctioning of gastric contents or blood clots and passage of larger accessories. An assistance of water jet is preferred as it helps in better visualization of lesions and successful endotherapy administration. Distal attachment cap further enhances the visualization. Duodenoscope can be used to address lesions located in the posterior duodenal wall or second part of duodenum.

\section{Scanning Endoscopy}

A keen observation is prerequisite while performing endoscopy. Esophagus should be carefully inspected for lesions such as Mallory-Weiss tear as retching during endoscopy can itself lead to such kind of lesions and may cause a diagnostic dilemma. If blood or clots are present in the fundus, first examine distally for any source of bleed. For visualizing the fundus, change of patient position to the reverse Trendelenburg, supine or right lateral position can be tried. Suction of gastric contents using large bore suction channel or using clot busting tubing/6-mm channel, removal of clots using retrieval nets, gastric lavage using wide bore NG tubes, or administering prokinetics before endoscopy are useful strategies to clear fundal contents. Since identification of one lesion does not preclude occurrence of another concomitant lesion, UGIE should be religiously performed examining all the segments.

\section{Endoscopic Classification}

Forrest's classification is widely used to stratify risk of recurrent bleed and need for endotherapy in patients with peptic ulcer ${ }^{39}$ and has been summarized with its rebleeding risks in Supplementary Table S2 (available in the online version). In a large RCT, Forrest's IB is associated with significantly lower rebleeding risk compared with Forrest's IA, IIA, and IIB. Based on these results, peptic ulcers are reclassified as high risk (Forrest's IA, IIA. and IIB), intermediate risk (Forrest's IB and IIC), and low risk (Forrest's III). ${ }^{40}$ The choice of therapy also needs consideration for other factors such as site and size of ulcer, surrounding tissue, and presence of any visible vessel. ${ }^{41}$

\section{Methods of Endoscopic Hemostasis}

The three major categories of endoscopic hemostatic techniques are injection therapy, thermal methods, and mechanical methods. Injection therapy is done using agents such as epinephrine, sclerosing agents (absolute alcohol, ethanolamine, and polidocanol), and tissue adhesives (fibrin, thrombin, and cyanoacrylate glue). Contact thermal methods include heater probe, monopolar or bipolar electrocautery, and hemostatic forceps. Noncontact thermal methods include argon plasma coagulation (APC). Mechanical methods 
include various types of through the scope (TTS) hemoclips and cap-assisted devices (OVESCO \& Padlock). Topical hemostatic agents are upcoming noncontact methods to manage tumor-related bleed or any other diffuse bleed.

\section{Conventional Methods}

The various conventional methods encompass injection therapy with epinephrine, through-the-scope (TTS) clips, and thermal methods such as heater probe, gold probe, and APC. Epinephrine injection in combination with either thermal or mechanical therapy is recommended to manage Forrest's IA and IB ulcers. ${ }^{25}$ However, for these high-risk lesions, adequate hemostasis can be achieved with either mechanical or thermal therapy alone. Monotherapy with thermal or mechanical methods is usually recommended for Forrest's IIA ulcers. ${ }^{25,26}$ Adherent clots, in cases of Forrest's IIB ulcers, should be removed using polypectomy snare, after which the stigmata of underlying vessel will direct the choice of subsequent endotherapy. Forrest's IIC and III lesions are associated with minimal rebleed risk and hence these patients can be discharged on oral PPI therapy alone..$^{25,26}$

\section{Injection Therapy}

\section{Technical Aspect}

Endoscopic injection is performed using 19- to 25 -gauge needles which consist of an outer sheath and an inner hollow-core needle. For safe passage through the working channel, needle should be retracted into the plastic sheath. At the site of bleeding, the needle is extended out of the sheath and the solution is injected into the mucosa. Injection epinephrine (1:10,000 or $1: 20,000$ with normal saline) is injected in 0.5 to $2 \mathrm{~mL}$ aliquots in and around ulcer base. The primary mechanism of injection therapy is local tamponade resulting from a volume effect, so higher injected volume results in better hemostasis. A minimum of 5 to $10 \mathrm{~mL}$ is required for tamponade effect, better results are obtained with 10 to $30 \mathrm{~mL}$. Volume of $>30 \mathrm{~mL}$ increases risk of complications/perforations and should be avoided. Diluted epinephrine also have a secondary effect due to local vasoconstriction. Sclerosing agents, such as ethanol, ethanolamine, and polidocanol, produce hemostasis by causing direct tissue injury and thrombosis. Tissue adhesives including thrombin, fibrin, and cyanoacrylate glues create a primary seal at the site of bleeding.

\section{Efficacy}

Monotherapy using adrenaline should never be used because of high risk of rebleed. Head-to-head comparison with thermal and mechanical therapy showed comparable efficacy but significantly higher rebleeding rate in case of injection therapy. ${ }^{42-44}$ Adrenaline stops bleeding transiently by causing vasospasm and local tamponade and allows better visualization and successful application of mechanical or thermal therapy afterward. ${ }^{45}$ However, some recent studies have shown that thermal or mechanical monotherapy is as good as combination therapy. ${ }^{46,47}$

\section{Mechanical Methods}

Conventional methods of mechanical therapy includes TTS hemoclips. Variety of hemoclips having different properties is available and is summarized in Supplementary Table S3 (available in the online version). ${ }^{48}$ Hemoclip is deployed directly onto a bleeding vessel and it sloughs off within days to weeks after placement. The choice of these hemoclips depends on ulcer-related parameters and characteristics of the hemoclip like tensile strength, rotatability, and others. For confined spaces, use of a smaller clip with precise open and close system are preferred while for therapies with scope in full retroflexion or using duodenoscope elevator, clips with 360-degree rotatability are preferred. Clips with higher compression force are better for fibrotic and large ulcers. ${ }^{49}$

\section{Technical Aspects}

The clip is extended out of sheath after insertion of the delivery catheter through the working channel. The clip and target should be kept close to endoscope. The clip is opened with plunger handle and then positioned over the target area in tangential or enface approach either by repositioning of endoscope or by rotation of the clip. The target area is then grasped between jaws of the clips and clip is applied using the device handle. Slight suction before deployment of clip enables maximum tissue capture.

\section{Efficacy}

Primary hemostasis rate is 80 to $90 \%$ and comparable to thermal therapy ${ }^{46,50,51}$ Meta-analysis comparing injection, thermal, and mechanical therapies concluded similar efficacy of each modalities for primary hemostasis but higher rebleeding rate if injection monotherapy was used. ${ }^{42-44}$

\section{Thermal Methods}

Conventional thermal methods are divided into two types: contact and noncontact thermal devices. Contact thermal methods include heater probe, monopolar, or bipolar electrocautery. Noncontact thermal methods include APC. Supplementary Table S4 (available in the online version) summarizes the various available thermal therapeutic modalities. ${ }^{48}$

\section{Technical Aspect}

Contact thermal devices generate heat which results in edema, coagulation of tissue proteins, and vasoconstriction. Mechanical pressure is also applied on probe tip for local tamponade combined with coagulation, a process known as "coaptive coagulation." At least 8 seconds of forceful contact time of probe should be allowed for adequate hemostasis. Endoscope should be held as close to the treatment site to ensure obliteration of culprit vessel. Generator settings for thermal therapy are as follows: for heater probe, 25 to $30 \mathrm{~J} /$ pulse, 4 to 5 pulse (total $100-150 \mathrm{~J}$ ); and for bipolar/multipolar probes, 15 to 20 Watts. Area and depth of tissue injury is limited by decreased electrical conductivity as the target tissue desiccates. 
APC uses high frequency, monopolar alternating current resulting in coagulation of superficial tissue. The electrons flow through a stream of electrically activated ionized argon gas causing tissue desiccation at the surface. Electrosurgical unit generator settings for APC include soft coagulation mode, $40 \mathrm{~W}$ energy, and gas flow of 1 to $2 \mathrm{~L} /$ minute. Optimum distance from the probe tip to the target tissue should be around 2 to $8 \mathrm{~mm}$.

\section{Efficacy}

Head-to-head comparison between mechanical and thermal therapy shows variable results. However, majority of studies have reported their equivalent efficacy (-Table $\mathbf{1}$ ). Hence, the choice of therapy depends on availability of hemostatic modality and discretion of the endoscopist. In cases where there is a difficult location for successful hemoclip deployment or the lesion has a surrounding fibrotic bed, thermal therapy can be preferentially considered. Similarly hemoclips can be preferred in anticoagulant-related bleeding lesions as they cause limited tissue injury.

\section{Newer Modalities}

Despite recent advances, the conventional methods fails to achieve hemostasis in 10 to $24 \%$ of NVUGIH cases. Ulcer size $>2 \mathrm{~cm}$, visible vessel $>2 \mathrm{~mm}$, location at posterior duodenal wall, or along lesser curvature, underlying gastroduodenal or left gastric artery and fibrotic ulcer bed are predictors of failure for conventional methods. ${ }^{41,53}$ To overcome these limitations of conventional therapy, newer endoscopic modalities have been developed and studied in patients with NVUGIH. These newer modalities include over-the-scope clips, hemostatic forceps, hemostatic sprays, radiofrequency ablation, cryotherapy, endoscopic suturing devices, and endoscopic ultrasound (EUS) guided angiotherapy. ${ }^{7}$

\section{Hemostatic Forceps (Coagrasper) \\ Technical Aspect}

Hemostatic forceps (HF) first gained popularity in its use for hemostasis during Per oral endoscopic myotomy (POEM) and endoscopic submucosal dissection (ESD). ${ }^{54}$ Antislip jaw further increase its efficacy. ${ }^{55,56}$ For ulcer bleed or bleeding vessel, HF can be applied, using soft coagulation, directly by contacting the bleeding point/vessel with the closed tip or by catching the vessel. The risk of perforation is extremely low because of using lower voltage and without any carbonization. Potential disadvantages of HF is a reduced coagulation effect in presence of blood, clots, or water between the tip of the forceps and the bleeding point. Additionally, patients with pacemakers and implantable cardioverter-defibrillators need to have their cardiac device mode adjusted.

\section{Efficacy}

One RCT comparing Coagrasper and heater probe reported primary hemostasis in $96 \%$ patients treated with Coagrasper compared with $67 \%$ in the other group. ${ }^{55}$ Another RCT reported higher initial success rate, lower rebleed rates, fewer adverse events, and shorter procedure time in patients receiving hemostasis using HF compared with patients managed with hemoclips ${ }^{56}$ (-Table 2). Guidelines recommended hemostatic forceps as alternative treatment option of hemostasis in patients with ulcer-related bleed.

\section{Cap-Mounted Clips}

Cap-mounted clips (e.g., Over the Scope Clip [OTSC], OVESCO Endoscopy, Germany; and Padlock system, Steris Endoscopy) have been evaluated in treating NVUGIH as first line or salvage therapy (-Table $\mathbf{2}$ ).

\section{Technical Aspects}

Cap-assisted devices utilize an applicator cap preloaded with a nitinol clip that fits onto the tip of the endoscope. In the OTSC system, the cap-mounted clip is affixed to the tip of the endoscope. A clip-release thread is retrogradely pulled through the working channel and is fixed onto a hand wheel. The clip is released by turning the hand wheel in a manner similar to deploying a variceal ligation band. The Padlock system is installed on the handle of the endoscope and connects to the clip by a linking cable delivery system on the outside of the endoscope. Padlock system deploys its clip using "Lock-it" releasing mechanism. Accurate positioning and adequate retraction of tissue into the cap of the device is required before the clip can be properly deployed. Due to its unique design and elastic properties of nitinol, cap-assisted devices close itself, and ensures therapeutic effects.

\section{Efficacy}

In a retrospective study (FLETRock study), OTSC was found to be effective as a first-line therapy in high-risk ulcer patients. ${ }^{59}$ Meta-analysis of 21 studies showed 97\% efficacy of OTSC as first line therapy. ${ }^{60}$ A study comparing cap-assisted clips versus standard therapy as first line treatment of NVUGIH reported OTSC to be more effective, as well as safe. ${ }^{62}$ In a multicenter RCT ('STING' trial) of patients with recurrent bleed, OTSC was found to be more effective than conventional mechanical and thermal therapies. ${ }^{63}$ Based on these evidences, recent guidelines recommend cap-assisted clips as the first-line therapy in patients with high-risk ulcers and as a rescue therapy after failed conventional methods and in patients with recurrent bleed.

\section{Topical Hemostatic Powder}

Topical hemostatic powders (TC-325, Endoclot \& UI-EWD) have been found to be effective in patients with bleeding related to tumor, ulcer, and those having diffuse ooze from the mucosal surface ( - Table 2 ).

\section{Technical Aspects}

C-325 or hemospray (Cook Medical) is an inorganic, absorbent powder which concentrates clotting factors at the bleeding site and forms a coagulum. The coagulum typically sloughs within 3 days and is naturally eliminated. Hemospray consists of a pressurized $\mathrm{CO}_{2}$ canister, a TTS delivery catheter, and a reservoir for the powder cartridge. Endoclot (Endoclot Plus, Santa Clara, California, United States) is a biocompatible starch-derived compound that rapidly absorbs water from serum and concentrates coagulation factors, platelets, and red blood cells at the bleeding site. Another hemostatic powder 
Table 1 Studies on comparative efficacy of different conventional hemostatic modalities

\begin{tabular}{|c|c|c|c|c|c|c|c|}
\hline $\begin{array}{l}\text { Studies } \\
\text { (year) }\end{array}$ & $\begin{array}{l}\text { Study } \\
\text { design }\end{array}$ & $\begin{array}{l}\text { Study } \\
\text { participants }\end{array}$ & $\begin{array}{l}\text { No. of } \\
\text { patients }\end{array}$ & $\begin{array}{l}\text { Injection } \\
\text { therapy }\end{array}$ & $\begin{array}{l}\text { Mechanical } \\
\text { therapy }\end{array}$ & $\begin{array}{l}\text { Thermal } \\
\text { therapy }\end{array}$ & Observation \\
\hline $\begin{array}{l}\text { Saltzman et } \\
\text { al }(2005)^{46}\end{array}$ & Prospective & $\begin{array}{l}\text { Forrest's I } \\
\text { and II } \\
\text { Forrest's I, } n= \\
22, \text { Forrest's } \\
\text { IIA, } n=13, \\
\text { and Forrest's } \\
\text { IIB, } n=12\end{array}$ & 47 & $\begin{array}{l}21 \text { patients } \\
\text { (epineph- } \\
\text { rine along } \\
\text { with } \mathrm{MPEC} \text { ) }\end{array}$ & $\begin{array}{l}26 \text { (TTS } \\
\text { hemoclips) }\end{array}$ & $\begin{array}{l}21 \text { (MPEC + } \\
\text { epinephrine) }\end{array}$ & $\begin{array}{l}\text { Primary hemostasis, } \\
\text { rebleed rate, need of blood } \\
\text { transfusion, hospital stay, } \\
\text { surgery, and mortality were } \\
\text { comparable }\end{array}$ \\
\hline $\begin{array}{l}\text { Cipolletta et } \\
\text { al }(2001)^{50}\end{array}$ & RCT & $\begin{array}{l}\text { Patient with } \\
\text { ulcer related } \\
\text { bleed with } \\
\text { SRH }\end{array}$ & 113 & - & $\begin{array}{l}56 \text { (TTS } \\
\text { hemoclips) }\end{array}$ & $\begin{array}{l}57 \text { (heater } \\
\text { probe) }\end{array}$ & $\begin{array}{l}\text { Primary hemostasis, 30-day } \\
\text { mortality, and emergency } \\
\text { surgery were comparable. } \\
\text { Recurrent bleed, need of } \\
\text { blood transfusion, and } \\
\text { hospital stay were lower in } \\
\text { hemoclip group }\end{array}$ \\
\hline $\begin{array}{l}\text { Lin et al } \\
(2002)^{51}\end{array}$ & RCT & $\begin{array}{l}\text { Active bleed- } \\
\text { ing ulcer and } \\
\text { NBVV were } \\
\text { included }\end{array}$ & 80 & - & $\begin{array}{l}40 \text { (TTS } \\
\text { hemoclips) }\end{array}$ & $\begin{array}{l}40 \text { (heater } \\
\text { probe) }\end{array}$ & $\begin{array}{l}\text { Primary hemostasis was } \\
\text { significantly better for heater } \\
\text { probe especially for diffi- } \\
\text { cult to approach bleeding. } \\
\text { Recurrent bleed, need of } \\
\text { blood transfusion, hospital } \\
\text { stay, surgery, and mortality } \\
\text { were comparable }\end{array}$ \\
\hline $\begin{array}{l}\text { Lin et al } \\
(2003)^{47}\end{array}$ & $\mathrm{RCT}$ & $\begin{array}{l}\text { Forrest's I } \\
\text { and II }\end{array}$ & 93 & $\begin{array}{l}47 \\
\text { (hypertonic } \\
\text { saline-epi- } \\
\text { nephrine } \\
\text { injection } \\
\text { along with } \\
\text { heater } \\
\text { probe) }\end{array}$ & $\begin{array}{l}46(5 \\
\text { excluded d/t } \\
\text { technical } \\
\text { failure }\end{array}$ & $\begin{array}{l}47 \text { (heater } \\
\text { probe + } \\
\text { hypertonic } \\
\text { saline-ep- } \\
\text { inephrine } \\
\text { injection }\end{array}$ & $\begin{array}{l}\text { Primary hemostasis, } \\
\text { rebleed rate, need of blood } \\
\text { transfusion, hospital stay, } \\
\text { surgery, and mortality were } \\
\text { comparable }\end{array}$ \\
\hline $\begin{array}{l}\text { Peng et al } \\
(2013)^{52}\end{array}$ & Retrospective & $\begin{array}{l}\text { Forrest's I } \\
\text { and II }\end{array}$ & 194 & - & $\begin{array}{l}84 \text { (TTS } \\
\text { hemoclips) }\end{array}$ & $\begin{array}{l}110 \text { (inter- } \\
\text { mediate } \\
\text { dose APC) }\end{array}$ & $\begin{array}{l}\text { Recurrent bleeding at } 1 \\
\text { week and at } 1 \text { month, blood } \\
\text { transfusion requirement, } \\
\text { surgery, and mortality were } \\
\text { comparable. Hospital stay } \\
\text { was significantly shorter in } \\
\text { APC group }\end{array}$ \\
\hline $\begin{array}{l}\text { Sung et al } \\
(2007)^{42}\end{array}$ & $\begin{array}{l}\text { Meta-analysis } \\
\text { including } 15 \\
\text { RCTs }\end{array}$ & & 1,156 & $\begin{array}{l}359 \text { injec- } \\
\text { tion alone }\end{array}$ & $\begin{array}{l}390 \text { TTS } \\
\text { clips alone, } \\
242 \text { clips + } \\
\text { injection }\end{array}$ & $\begin{array}{l}165 \text { thermo- } \\
\text { coagulation } \\
\text { with/without } \\
\text { injection }\end{array}$ & $\begin{array}{l}\text { Definitive hemostasis, need } \\
\text { of surgery, and mortality } \\
\text { were comparable between } \\
\text { thermal and mechanical ther- } \\
\text { apies. Higher rebleed rate, } \\
\text { need of surgery but no differ- } \\
\text { ence in mortality if injection } \\
\text { therapy alone was used }\end{array}$ \\
\hline $\begin{array}{l}\text { Marmo et al } \\
(2007)^{43}\end{array}$ & $\begin{array}{l}\text { Meta-analysis } \\
\text { including } 20 \\
\text { RCTs }\end{array}$ & $\begin{array}{l}\text { Combination } \\
\text { therapy vs. } \\
\text { monotherapy }\end{array}$ & $\begin{array}{l}\text { Total } \\
\text { patients }= \\
2,472 \text {. Dual } \\
\text { therapy, } n= \\
1,233 \text { and } \\
\text { monother- } \\
\text { apy, } n= \\
1,239\end{array}$ & $\begin{array}{l}\text { Injection } \\
+ \text { clips vs. } \\
\text { injection } \\
\text { alone, } n= \\
362 \\
\text { Injection + } \\
\text { thermal vs. } \\
\text { injection } \\
\text { alone, } n= \\
376, \\
\text { Injection } \\
+ \text { injection } \\
\text { vs. injec- } \\
\text { tion mono- } \\
\text { therapy, } n \\
=1,075\end{array}$ & $\begin{array}{l}\text { Injection + } \\
\text { clips vs. clip } \\
\text { monother- } \\
\text { apy, } n=234\end{array}$ & $\begin{array}{l}\text { Injection } \\
+ \text { thermal } \\
\text { vs. thermal } \\
\text { monother- } \\
\text { apy, } n=425\end{array}$ & $\begin{array}{l}\text { Dual therapy was better } \\
\text { to injection monotherapy } \\
\text { but not superior to either } \\
\text { mechanical or thermal } \\
\text { monotherapy in re-bleed } \\
\text { rate, emergency surgery, and } \\
\text { mortality }\end{array}$ \\
\hline
\end{tabular}


Table 1 (Continued)

\begin{tabular}{|c|c|c|c|c|c|c|c|}
\hline $\begin{array}{l}\text { Studies } \\
\text { (year) }\end{array}$ & $\begin{array}{l}\text { Study } \\
\text { design }\end{array}$ & $\begin{array}{l}\text { Study } \\
\text { participants }\end{array}$ & $\begin{array}{l}\text { No. of } \\
\text { patients }\end{array}$ & $\begin{array}{l}\text { Injection } \\
\text { therapy }\end{array}$ & $\begin{array}{l}\text { Mechanical } \\
\text { therapy }\end{array}$ & $\begin{array}{l}\text { Thermal } \\
\text { therapy }\end{array}$ & Observation \\
\hline $\begin{array}{l}\text { Vergara et al } \\
(\mathbf{2 0 1 4})^{45}\end{array}$ & $\begin{array}{l}\text { Meta-analysis } \\
\text { including } 19 \\
\text { RCTs }\end{array}$ & $\begin{array}{l}\text { Forrest's IA, } \\
\text { IB, IIA, and IIb } \\
\text { ulcer patients } \\
\text { received injec- } \\
\text { tion epineph- } \\
\text { rine alone vs. } \\
\text { epinephrine } \\
\text { with second } \\
\text { modality }\end{array}$ & 2,033 & \begin{tabular}{l|}
12 studies \\
compared \\
injection \\
epineph- \\
rine vs. \\
epinephrine \\
+ second \\
injection \\
therapy
\end{tabular} & $\begin{array}{l}\text { Four studies } \\
\text { compared } \\
\text { injection } \\
\text { epinephrine } \\
\text { + clips vs. } \\
\text { injection } \\
\text { epinephrine } \\
\text { alone }\end{array}$ & $\begin{array}{l}\text { Three studies } \\
\text { compared } \\
\text { injection. } \\
\text { epinephrine } \\
\text { + thermal } \\
\text { therapy vs. } \\
\text { injection } \\
\text { epinephrine } \\
\text { alone }\end{array}$ & $\begin{array}{l}\text { Combination therapy } \\
\text { reduces persistent and } \\
\text { recurrent bleeding rate and } \\
\text { need of emergency surgery } \\
\text { compared with injection } \\
\text { Epinephrine alone. Mortality } \\
\text { and adverse events not } \\
\text { significantly different in } \\
\text { combination and epinephrine } \\
\text { alone groups }\end{array}$ \\
\hline $\begin{array}{l}\text { Calvet et al } \\
(2004)^{44}\end{array}$ & $\begin{array}{l}\text { Meta-analysis } \\
\text { including } 16 \\
\text { RCTs }\end{array}$ & $\begin{array}{l}\text { Forrest's IA, } \\
\text { IB, IIA, and IIb } \\
\text { ulcer patients } \\
\text { received injec- } \\
\text { tion epineph- } \\
\text { rine alone vs. } \\
\text { epinephrine } \\
\text { with second } \\
\text { modality }\end{array}$ & 1,673 & \begin{tabular}{l|}
11 studies \\
compared \\
injection \\
epineph- \\
rine vs. \\
epinephrine \\
+ second \\
injection \\
therapy
\end{tabular} & $\begin{array}{l}\text { Two studies } \\
\text { compared } \\
\text { injection } \\
\text { epinephrine } \\
\text { + clips vs. } \\
\text { injection } \\
\text { epinephrine } \\
\text { alone }\end{array}$ & $\begin{array}{l}\text { Three studies } \\
\text { compared } \\
\text { injection } \\
\text { epinephrine } \\
\text { + thermal } \\
\text { therapy vs. } \\
\text { injection } \\
\text { epinephrine } \\
\text { alone }\end{array}$ & $\begin{array}{l}\text { Adding a second method to } \\
\text { injection epinephrine reduced } \\
\text { recurrent bleed, surgery, and } \\
\text { mortality. Beneficial effect } \\
\text { of adding second modality } \\
\text { achieved regardless of which } \\
\text { second hemostatic modality } \\
\text { was applied }\end{array}$ \\
\hline
\end{tabular}

Abbreviations: APC, argon plasma coagulation; MPEC, multipolar electrocoagulation; RCT, randomized controlled trial; TTS, through-the-scope clip; NBVV, non-bleeding visible vessel; SRH, stigmata of recent hemorrhage.

available in India is hemoseal powder (Shaili Endoscopy, Gujarat, India) which is collagen powder.

The hemostatic powder is delivered via a spray catheter placed through the endoscope's working channel. During hemospray use, caution is required to prevent catheter block. Moisture should be avoided coming into contact with the catheter by preflushing of the accessory channel with $60 \mathrm{~mL}$ of air and detachment of suctioning tubing prior to insertion. The deploying catheter should be kept 1- to 2-cm away from bleeding site. Caution is required when using elevator in duodenoscopes or in retroflexed position to avoid kinking.

\section{Efficacy}

In a multicenter registry of patients with peptic ulcer bleed, topical hemostatic agents were found to be $86 \%$ effective for primary hemostasis with $12.7 \%$ rebleed rate. ${ }^{69}$ Another RCT compared hemostatic powder with mechanical therapy (TTS) and reported no difference in rebleed, need of surgery, and mortality risk in two groups. ${ }^{70}$ Advantages of hemostatic powders include ease of application, efficacy in diffuse bleed with poor visualization, and tumor-related bleed. Potential disadvantages include rebleed, limited efficacy in Forrest's IA ulcers due to rapid wash away effect, and efficacy only in presence of active bleeding ( - Table 3 ). Recent guidelines recommend topical hemostatic powder as a temporary measure of rescue after failed conventional treatment, recurrent bleed, diffuse bleed, and tumor-related bleed.

\section{Endoscopic Suturing}

Endoscopic suturing device (Overstitch, Apollo Endo-surgery, United States) has been evaluated in patients with ulcer-related bleed, particularly large, and deep and fibrotic ulcers. Various case reports and case series have reported a high success rate, as well as safety of this modality, in patients with large ulcers. ${ }^{72,73}$ Endoscopic suturing is limited by high rebleeding rate (29-38\%), need of double channel therapeutic endoscope, and expert endoscopic skills (-Table 3). Endoscopic suturing is contraindicated in suspected malignant ulcers.

\section{Endoscopic Ultrasound-Guided Intervention}

EUS-guided angiotherapy is a promising modality for bleeding lesions that are inaccessible or refractory to standard endoscopic techniques. Most common lesions treated by EUS angiotherapy include Dieulafoy's lesions, pseudoaneurysm, and gastrointestinal stromal tumors. ${ }^{74,75}$ Hemostasis is achieved using coils, cyanoacrylate/fibrin glue, or sclerosing agents (absolute alcohol and polidocanol). EUS-guided angiotherapy has been mostly used as a rescue therapy after failed conventional modalities. ${ }^{75}$

\section{Endoscopic Doppler Ultrasound Probe}

Endoscopic Doppler probes (EDPs) are currently available to guide hemostasis in patients with high risk of rebleed. Two EDPs are available at present: (1) the VTI Endoscopic Doppler system (Vascular Technology Inc., Massachusetts, United States) and (2) endo-DOP system ( $\mathrm{GmbH}$, Singen, Germany). While the VTI uses a $1.5-\mathrm{mm}$ diameter probe using $20 \mathrm{MHz}$, the endo-DOP uses a 1.8-mm diameter probe with $16 \mathrm{MHz}$. The probe is applied at the bleeding point to pick up Doppler signals corresponding to the presence and course of the underlying vessels. Postendotherapy disappearance of signals can hint at success of therapy. One comparative study reported lower recurrent bleeding, surgery, and bleeding-related mortality in patients who received EDP-guided hemostasis compared with patients who received conventional treatment. ${ }^{76}$ Another study reported significantly lower rebleed rate, surgery, and major complications in patients who received EDP-guided hemostasis. ${ }^{77}$ 
Table 2 Studies on newer hemostatic modalities

\begin{tabular}{|c|c|c|c|c|c|c|}
\hline Study (year) & $\begin{array}{l}\text { Design of } \\
\text { study }\end{array}$ & Study participants & $\begin{array}{l}\text { No. of } \\
\text { patients }\end{array}$ & $\begin{array}{l}\text { Newer } \\
\text { hemostatic } \\
\text { modality }\end{array}$ & $\begin{array}{l}\text { Conventional } \\
\text { method }\end{array}$ & Observations \\
\hline $\begin{array}{l}\text { Kim et al } \\
(2015)^{54}\end{array}$ & $\begin{array}{l}\text { Prospective } \\
\text { RCT }\end{array}$ & $\begin{array}{l}\text { Forrest's IA, IB, } \\
\text { and IIA }\end{array}$ & 151 & $\begin{array}{l}\text { HFSC }+ \\
\text { injection } \\
\text { epinephrine: } \\
n=76\end{array}$ & $\begin{array}{l}\text { APC }+ \\
\text { injection } \\
\text { epinephrine: } \\
n=75\end{array}$ & $\begin{array}{l}\text { Primary hemostasis, recurrent bleed } \\
\text { at } 30 \text { days, rate of adverse events, } \\
\text { and mortality were comparable } \\
\text { between HFSC and APC groups }\end{array}$ \\
\hline $\begin{array}{l}\text { Nunoue et al } \\
(2015)^{55}\end{array}$ & RCT & $\begin{array}{l}\text { Forrest's IA, IB, IIA, } \\
\text { and IIb }\end{array}$ & 111 & $\begin{array}{l}\text { Monopolar } \\
\text { HFSC } \\
\text { (group S): } \\
n=56\end{array}$ & $\begin{array}{l}\text { Heater probe: } \\
n=55\end{array}$ & $\begin{array}{l}\text { Primary hemostasis was higher in soft } \\
\text { coagulation group ( } 96 \text { vs. } 67 \%, p< \\
0.001 \text { ). Recurrent bleed was lower in } \\
\text { soft coagulation group ( } 13 \text { vs. } 0 \%, p \\
<0.01 \text { ) }\end{array}$ \\
\hline $\begin{array}{l}\text { Arima et al } \\
(\mathbf{2 0 1 0})^{56}\end{array}$ & RCT & $\begin{array}{l}\text { Forrest's IA, IB, IIA, } \\
\text { and IIb }\end{array}$ & 96 & $\begin{array}{l}\text { Monopolar } \\
\text { HFSC: } n=48\end{array}$ & $\begin{array}{l}\text { Hemoclips: } \\
n=48\end{array}$ & $\begin{array}{l}\text { Primary hemostasis, recurrent bleed, } \\
\text { surgery, and mortality comparable } \\
\text { between both the groups. Time to } \\
\text { achieve hemostasis was significantly } \\
\text { shorter in soft coagulation group }\end{array}$ \\
\hline $\begin{array}{l}\text { Kataoka et al } \\
(2013)^{57}\end{array}$ & Prospective & $\begin{array}{l}\text { Forrest's IA, IB, } \\
\text { and IIA }\end{array}$ & 50 & $\begin{array}{l}\text { Bipolar HFSC: } \\
n=27\end{array}$ & $\begin{array}{l}\text { Hemoclips: } \\
n=23\end{array}$ & $\begin{array}{l}\text { Primary hemostasis was better in } \\
\text { hemostatic forceps group ( } 100 \text { vs. } \\
78.2 \%, p<0.05) \text {. Recurrent bleed and } \\
\text { procedure time were not significantly } \\
\text { different }\end{array}$ \\
\hline $\begin{array}{l}\text { Richter-Schrag } \\
\text { et al }(2016)^{58}\end{array}$ & Retrospective & $\begin{array}{l}\text { UGIB }(n=69) \text {, LGIB } \\
(n=31) \text {. Forrest's } \\
\text { IA, IB, IIA, and IIb } \\
\text { in case of ulcer } \\
\text { bleed and spurting } \\
\text { and oozing in case } \\
\text { of other etiology } \\
\text { of bleed were } \\
\text { enrolled }\end{array}$ & 100 & $\begin{array}{l}\text { OTSC as } \\
\text { FLET or SLET } \\
\text { after failed } \\
\text { conventional } \\
\text { method }\end{array}$ & - & $\begin{array}{l}\text { Primary hemostasis and clinical } \\
\text { success was } 88 \text { and } 77 \% \text { respec- } \\
\text { tively. OTSC when used as SLET have } \\
\text { significantly higher re-bleeding rate } \\
\text { compared with FLET }\end{array}$ \\
\hline $\begin{array}{l}\text { Wedi et al } \\
(2018)^{59}\end{array}$ & Retrospective & \begin{tabular}{|l|} 
NVUGIB patients \\
underwent OTSC as \\
FLET were included
\end{tabular} & 118 & $\begin{array}{l}\text { OTSC as FLET } \\
\text { were included }\end{array}$ & & $\begin{array}{l}\text { Primary successful hemostasis was } \\
\text { achieved in } 92.4 \% \text {. Compared with } \\
\text { Rockall's risk category prediction, } \\
\text { OTSC reduced persistent, and recur- } \\
\text { rent bleed and rebleeding related } \\
\text { mortality }\end{array}$ \\
\hline $\begin{array}{l}\text { Chandrasekar } \\
\text { et al }(2019)^{60}\end{array}$ & $\begin{array}{l}\text { Meta-analysis } \\
\text { including } 21 \\
\text { studies }\end{array}$ & $\begin{array}{l}\text { Upper and lower GI } \\
\text { bleeding patients } \\
\text { treated with OTSC } \\
\text { as first-line or sec- } \\
\text { ond-line treatment } \\
\text { were included }\end{array}$ & 851 & $\begin{array}{l}\text { OTSC } \\
\text { (OVESCO) }\end{array}$ & & $\begin{array}{l}\text { Definitive hemostasis was } 87.8 \% \text { after } \\
8 \text { weeks. Technical success, clinical } \\
\text { success, and rebleeding rates after } \\
\text { OTSC were } 97.8,96.6 \text {, and } 10.3 \% \text {, } \\
\text { respectively. Rebleeding was higher } \\
\text { when OTSC used as SLET compared } \\
\text { with FLET ( } 26 \text { vs. } 9 \% \text { ). }\end{array}$ \\
\hline $\begin{array}{l}\text { Gölder et al } \\
(\mathbf{2 0 1 9})^{61}\end{array}$ & $\begin{array}{l}\text { Prospective } \\
\text { study com- } \\
\text { paring OTSC } \\
\text { as FLET vs. } \\
\text { SLET }\end{array}$ & $\begin{array}{l}\text { Forrest's IA, IB, } \\
\text { and IIA gastric and } \\
\text { duodenal ulcers }\end{array}$ & 100 & $\begin{array}{l}\text { OTSC } \\
\text { (OVERSCO) } \\
\text { Primary } \\
\text { OTSC: } n=66 \\
\text { Secondary } \\
\text { OTSC: } n=34 \\
\end{array}$ & & $\begin{array}{l}\text { Successful hemostasis, recurrent } \\
\text { bleed, and clinical success were com- } \\
\text { parable between primary and second- } \\
\text { ary OTSC (90.9 vs. } 94.1,16.7 \text { vs. } 21.9 \text {, } \\
\text { and } 75.8 \text { vs. } 73.5 \% \text {, respectively) }\end{array}$ \\
\hline $\begin{array}{l}\text { Jensen et al } \\
(\mathbf{2 0 2 0})^{62}\end{array}$ & RCT & \begin{tabular}{|l|} 
Severe NVUGIH \\
Ulcers and \\
Dieulafoy's lesions, \\
Major SRH or lesser \\
stigmata with \\
arterial flow under- \\
neath documented \\
by Doppler probe \\
were included
\end{tabular} & 53 & OTSC: $n=25$ & $\begin{array}{l}\text { Standard } \\
\text { treatment } \\
\text { (hemoclips, } \\
\text { MPEC): } n=28\end{array}$ & $\begin{array}{l}\text { Significant differences in OTSC versus } \\
\text { Standard groups in rates of re-bleed- } \\
\text { ing ( } 4 \text { vs. } 28.6 \% ; p=0.017) \text {; severe } \\
\text { complications ( } 0 \text { vs. } 14.3 \% \text { ) and units } \\
\text { of red cell transfusions ( } 0.04 \text { vs. } 0.68 \text { ) }\end{array}$ \\
\hline
\end{tabular}


Table 2 (Continued)

\begin{tabular}{|c|c|c|c|c|c|c|}
\hline Study (year) & $\begin{array}{l}\text { Design of } \\
\text { study }\end{array}$ & Study participants & $\begin{array}{l}\text { No. of } \\
\text { patients }\end{array}$ & $\begin{array}{l}\text { Newer } \\
\text { hemostatic } \\
\text { modality }\end{array}$ & $\begin{array}{l}\text { Conventional } \\
\text { method }\end{array}$ & Observations \\
\hline $\begin{array}{l}\text { Schmidt et al } \\
(\mathbf{2 0 1 8})^{63}\end{array}$ & RCT & $\begin{array}{l}\text { Recurrent peptic } \\
\text { ulcer bleeding after } \\
\text { initial endoscopic } \\
\text { hemostasis were } \\
\text { included }\end{array}$ & 66 & OTSC: $n=33$ & $\begin{array}{l}\text { Standard } \\
\text { treatment: } \\
n=33 \text { (TTS } \\
\text { clips } n=31 \\
\text { thermal ther- } \\
\text { apy: } n=2 \text { ) }\end{array}$ & $\begin{array}{l}\text { Further bleeding (persistent or } \\
\text { recurrent bleeding within } 7 \text { days) } \\
\text { was significantly lower in OTSC group } \\
\text { ( } 15.2 \text { vs. } 57.6 \%, p=0.001) \text {. } \\
\text { Surgery, TAE, mortality, hospital } \\
\text { stay, complications, and transfusion } \\
\text { requirement were not different in } \\
\text { both the groups }\end{array}$ \\
\hline $\begin{array}{l}\text { Brandler et al } \\
(2018)^{64}\end{array}$ & Retrospective & $\begin{array}{l}\text { High-risk lesions } \\
\text { (>2 mm, situated } \\
\text { in area of a major } \\
\text { artery and/or a } \\
\text { deep penetrating, } \\
\text { excavated, fibrotic } \\
\text { ulcer with high-risk } \\
\text { stigmata, where a } \\
\text { perforation could } \\
\text { not be ruled out } \\
\text { or thermal therapy } \\
\text { would cause per- } \\
\text { foration, or those } \\
\text { that could not be } \\
\text { treated by standard } \\
\text { endoscopy }\end{array}$ & 67 & $\begin{array}{l}\text { OTSC as } \\
\text { primary } \\
\text { therapy: } \\
n=49 \text {, rescue } \\
\text { therapy: } \\
n=18\end{array}$ & & $\begin{array}{l}81.3 \% \text { success rate of OTSC at } 30 \\
\text { days. CAD was independent predic- } \\
\text { tors of rebleed }\end{array}$ \\
\hline $\begin{array}{l}\text { Haddara et al } \\
(2016)^{65}\end{array}$ & $\begin{array}{l}\text { Retrospective } \\
\text { registry }\end{array}$ & $\begin{array}{l}\text { Ulcers: } n=75 \\
\text { malignant lesions: } \\
n=61, \text { posten- } \\
\text { doscopy: } n=35 \\
\text { others: } n=31\end{array}$ & 202 & $\begin{array}{l}\text { Hemospray } \\
\text { (TC-325) } \\
\text { Primary } \\
\text { hemostatic } \\
\text { method: } \\
n=94 \text {, sal- } \\
\text { vage therapy: } \\
n=108\end{array}$ & & $\begin{array}{l}\text { Immediate hemostasis achieved in } \\
96.5 \% \text {. Recurrent bleeding at day } 8 \\
\text { and day } 30 \text { were } 26.7 \text { and } 33.5 \% \text {. } \\
\text { Rebleeding rate more if melena at } \\
\text { presentation and when TC- } 325 \text { used } \\
\text { as salvage therapy; } 26.7 \% \text { patients } \\
\text { required additional treatment }\end{array}$ \\
\hline $\begin{array}{l}\text { Chen et al } \\
(2015)^{66}\end{array}$ & $\begin{array}{l}\text { Retrospective } \\
\text { study }\end{array}$ & $\begin{array}{l}\text { Nonmalignant } \\
\text { NVUGIH: } n=21 \\
\text { Upper GI tumors: } \\
n=19, \text { LGIB: } n= \\
11, \text { intraprocedural } \\
\text { bleed: } n=16\end{array}$ & 67 & $\begin{array}{l}\text { Hemospray } \\
\text { (TC-325) }\end{array}$ & & $\begin{array}{l}\text { Primary hemostasis achieved in } 98.5 \% \\
\text { patients. Early rebleeding (within } 72 \\
\text { hours) occurred in } 9.5 \% \text { patients. No } \\
\text { serious adverse events reported }\end{array}$ \\
\hline $\begin{array}{l}\text { Prei et al } \\
(\mathbf{2 0 1 6})^{67}\end{array}$ & $\begin{array}{l}\text { Prospective } \\
\text { observational } \\
\text { study }\end{array}$ & $\begin{array}{l}\text { NVUGIB: } n=58, \\
\text { LGIB: } n=12\end{array}$ & 70 & $\begin{array}{l}\text { Hemostatic } \\
\text { powder } \\
\text { (Endoclot) } \\
\text { Primary ther- } \\
\text { apy: } n=56 \\
\text { Rescue ther- } \\
\text { apy: } n=14\end{array}$ & & $\begin{array}{l}\text { Overall treatment success rate was } \\
83 \% \text { with one week re-bleed rate of } \\
11.4 \% \text {. Endoclot was served as bridge } \\
\text { to surgery in } 10 \% \text { patients }\end{array}$ \\
\hline $\begin{array}{l}\text { Park et al } \\
(2019)^{68}\end{array}$ & $\begin{array}{l}\text { Retrospective } \\
\text { study }\end{array}$ & $\begin{array}{l}\text { Postendoscopy } \\
\text { bleeding: } n=46 \text {, } \\
\text { peptic ulcer: } n=8 \\
\text { tumor } n=1 \text {, other } \\
\text { etiology: } n=1\end{array}$ & 56 & $\begin{array}{l}\text { Hemostatic } \\
\text { adhesive } \\
\text { powder } \\
\text { (UI-EWD) }\end{array}$ & & $\begin{array}{l}\text { Technical success } 100 \% \text {, immediate } \\
\text { hemostasis } 96.4 \% \text {, rebleed at } 30 \text { days } \\
3.7 \% \text {, no adverse events }\end{array}$ \\
\hline $\begin{array}{l}\text { Alzoubaidi et al } \\
(\mathbf{2 0 2 0})^{69}\end{array}$ & $\begin{array}{l}\text { Prospective } \\
\text { study }\end{array}$ & $\begin{array}{l}\text { Peptic ulcer: } n= \\
\text { 167, malignancy: } \\
n=50, \text { posten- } \\
\text { doscopic therapy } \\
\text { bleed: } n=49 \\
\text { other: } n=48\end{array}$ & 314 & $\begin{array}{l}\text { Hemospray } \\
\text { (TC-325) }\end{array}$ & & $\begin{array}{l}\text { Initial hemostasis achieved in } 89.5 \% \text {, } \\
\text { recurrent bleed in } 10.3 \% \text {. Similar } \\
\text { hemostasis between Hemospray } \\
\text { monotherapy }(92.4 \%) \text {, combination } \\
\text { therapy }(88.7 \%) \text {, and rescue therapy } \\
(85.5 \%)\end{array}$ \\
\hline
\end{tabular}


Table 2 (Continued)

\begin{tabular}{|c|c|c|c|c|c|c|}
\hline Study (year) & $\begin{array}{l}\text { Design of } \\
\text { study }\end{array}$ & Study participants & $\begin{array}{l}\text { No. of } \\
\text { patients }\end{array}$ & $\begin{array}{l}\text { Newer } \\
\text { hemostatic } \\
\text { modality }\end{array}$ & $\begin{array}{l}\text { Conventional } \\
\text { method }\end{array}$ & Observations \\
\hline $\begin{array}{l}\text { Baracat et al } \\
(2020)^{70}\end{array}$ & RCT & $\begin{array}{l}\text { Peptic ulcer: } n= \\
\text { 26, malignancy: } n= \\
\text { 9, postendoscopic } \\
\text { therapy bleed: } n \\
=49, \text { postsphinc- } \\
\text { terotomy: } n=6 \text {, } \\
\text { Mallory-Weiss tear: } \\
n=4 \text {, Dieulafoy's } \\
\text { lesion: } n=2 \text {, other: } \\
n=11\end{array}$ & 39 & $\begin{array}{l}\text { Hemospray } \\
\text { (TC-325) } \\
+ \text { injection } \\
\text { epinephrine: } \\
n=19\end{array}$ & $\begin{array}{l}\text { Hemoclips } \\
+ \text { injection } \\
\text { epinephrine: } \\
n=20\end{array}$ & $\begin{array}{l}\text { Primary hemostasis, rebleed, } \\
\text { emergency surgery, and mortality } \\
\text { comparable between the groups. } \\
\text { Additional procedure required at } \\
\text { relook endoscopy in five patients in } \\
\text { Hemospray group compared with } \\
\text { none in Hemoclip group }(p=0.04 \text { ) }\end{array}$ \\
\hline $\begin{array}{l}\text { Prasad et al } \\
(2018)^{71}\end{array}$ & $\begin{array}{l}\text { Prospective } \\
\text { study }\end{array}$ & $\begin{array}{l}\text { Peptic ulcer related } \\
\text { bleed }\end{array}$ & $\begin{array}{l}18, \text { Forrest's } \\
I A=2, I B=16\end{array}$ & $\begin{array}{l}\text { Endoscopic } \\
\text { collagen } \\
\text { spray (hemo- } \\
\text { seal spray) }\end{array}$ & & $\begin{array}{l}\text { Hemostasis was achieved in all } \\
\text { patients. No rebleed after } 48 \text { hours. } \\
\text { No adverse drug reaction }\end{array}$ \\
\hline
\end{tabular}

Abbreviations: APC, argon plasma coagulation; FLET, first-line endoscopic therapy; GI, gastrointestinal; HFSC, hemostatic forceps with soft coagulation; LGIB, lower GI bleed; NVUGIB, nonvariceal upper GI bleed; MPEC, multipolar electrocoagulation; OTSC, over-the-scope clip; RCT, randomized controlled trial; SLET, second-line endoscopic therapy; SRH, stigmata of recent hemorrhage; TAE, transcatheter angiographic embolization; TTS, through-the-scope clip; UGIB, upper GI bleed; CAD coronary artery disease.

Table 3 Advantages and disadvantages of newer modalities

\begin{tabular}{|c|c|c|}
\hline $\begin{array}{l}\text { Hemostatic } \\
\text { modality }\end{array}$ & Advantages & Disadvantages \\
\hline OTSC & $\begin{array}{l}\text { - Advanced } \\
\text { endoscopy skills } \\
\text { not required } \\
\text { - Effective for } \\
\text { ulcers }>2 \mathrm{~cm}\end{array}$ & $\begin{array}{l}\text { Difficult to apply on } \\
\text { hard, fibrotic ulcers } \\
\text { - After identification } \\
\text { of bleeding source, } \\
\text { endoscope requires } \\
\text { to be withdrawn } \\
\text { and reinsertion after } \\
\text { mounting of OTSC } \\
\text { Cost }\end{array}$ \\
\hline $\begin{array}{l}\text { Endoscopic } \\
\text { suturing }\end{array}$ & $\begin{array}{l}\text { Effective for } \\
\text { large, hard, } \\
\text { fibrotic ulcers }\end{array}$ & $\begin{array}{l}\text { - Double-channel } \\
\text { endoscope needed } \\
\text { - Expert endoscopic } \\
\text { skills } \\
\text { - Cost }\end{array}$ \\
\hline Coagrasper & $\begin{array}{l}\text { - Safe and } \\
\text { effective } \\
\text { - Lower risk of } \\
\text { perforation }\end{array}$ & $\begin{array}{l}\text { - Ineffective if sub- } \\
\text { merge in water/large } \\
\text { surface area } \\
\text { - Cost }\end{array}$ \\
\hline Hemospray & $\begin{array}{l}\text { - Easy, safe, } \\
\text { effective } \\
\text { - Diffuse, poorly } \\
\text { localized bleed } \\
\text { - Malignancy } \\
\text { related bleed }\end{array}$ & $\begin{array}{l}\text { - Temporary method } \\
\text { - If fail, other modal- } \\
\text { ities cannot be used } \\
\text { immediately } \\
\text { - Works only if active } \\
\text { bleed }\end{array}$ \\
\hline $\begin{array}{l}\text { EUS-guided } \\
\text { angiography }\end{array}$ & $\begin{array}{l}\text { - Target under } \\
\text { direct vision } \\
\text { - Can confirm } \\
\text { hemostasis with } \\
\text { Doppler probe }\end{array}$ & $\begin{array}{l}\text { - Higher endoscopy } \\
\text { skills needed } \\
\text { - Resource intensive } \\
\text { - Costly }\end{array}$ \\
\hline
\end{tabular}

Abbreviations: EUS, endoscopic ultrasound; OTSC, over-the-scope clip; CAD, coronary artery disease.

Various causes of NVUGIH and their preferred hemostatic methods have been summarized in Supplementary Table S5 (available in the online version) and a flowchart for the possible management algorithm have been outlined in - Fig. 2.

\section{Persistent and Recurrent Bleed}

1. Persistent bleeding is defined as ongoing bleed despite standard hemostatic modality at the index endoscopy. Newer more effective modalities, like cap-mounted clips or hemostatic powder or Coagrasper, should be used as rescue therapy. If bleeding is refractory to all endoscopic hemostatic modalities, then transcatheter angiographic embolization (TAE) or surgery should be considered. Comparative studies between TAE and surgery reported higher rebleeding rate in case of TAE but lower adverse events and mortality compared with surgery. ${ }^{78,79}$

2. Recurrent bleeding is defined as recurrence of bleeding after successful hemostasis manifesting as ongoing hematemesis, persistent hemodynamic instability, recurrence of melena after initial resolution, and drop of hemoglobin $>2 \mathrm{~g} / \mathrm{dL}$ after initial stabilization. ${ }^{21}$ The predictors of recurrent bleeding include ulcers of $>2-\mathrm{cm}$ size, nonbleeding visible vessel $>2 \mathrm{~mm}$, ulcers located on posterior duodenal wall, and high on lesser curvature and persistent positive Doppler signals. Repeat endoscopy is recommended as $73 \%$ patients respond to a second endoscopic intervention. ${ }^{80}$ During second endoscopy, conventional methods or rescue therapy with cap-mounted clips, hemostatic powders/spray, or hemostatic forceps can be considered.

The STING trial showed that for rebleed, OTSC performed better than conventional methods. ${ }^{63}$ OTSC has a success rate of $81.3 \%$ at day-30 to control rebleed in patients with high risk of rebleed. ${ }^{64}$ Thus, cap-mounted clips can be considered as the first-line hemostatic measure in high-risk patients or with recurrent bleed. Various registries and case reports have shown approximately $95 \%$ success rate of topical hemostatic powders/spray when used as first line or salvage therapy for various causes of GI bleed. ${ }^{65-67}$ Soft coagulation, 


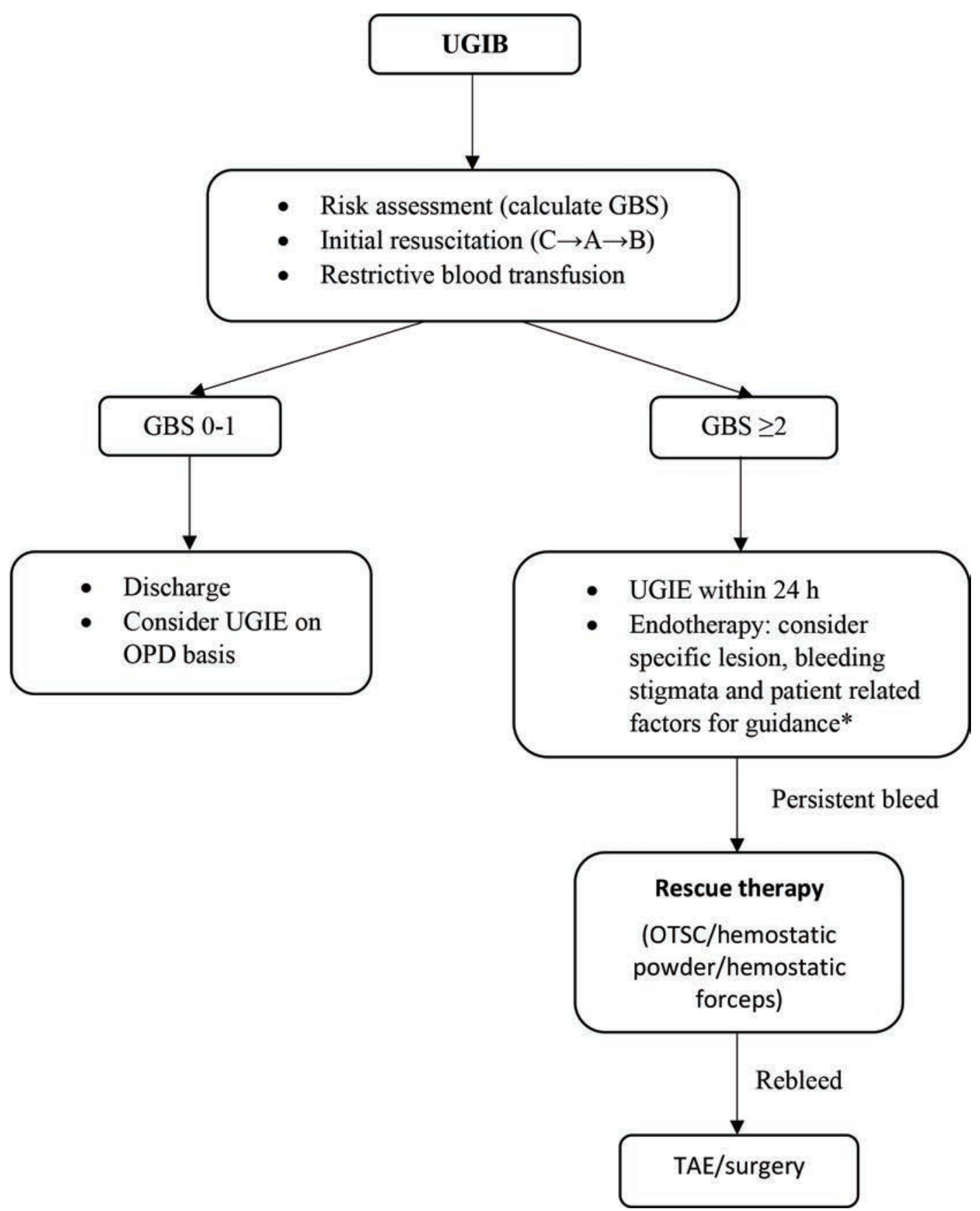

Fig. 2 Algorithm for the management of nonvariceal upper gastrointestinal hemorrhage (NVUGIH). GBS, Glasgow Blatchford scale; OPD, outpatient department; OTSC, over-the-scope clip; UGIB, upper gastrointestinal bleed; UGIE, upper gastrointestinal endoscopy; TAE, transcatheter angiographic embolization.

using hemostatic forceps, on head-to-head comparison with contact thermal/TTS clips showed higher rates of primary hemostasis, as well as lesser recurrent bleeding, although data exist for recurrent bleeding. ${ }^{55,57}$ Modified cyanoacrylate (cyanoacrylate associated with methacryloxysulfolane) can be used as rescue therapy in patients with NVUGIH with high success rate (78\%). ${ }^{81}$ In predicted high-risk ulcers, prophylactic TAE can reduce rebleed rate, though more robust data are needed. ${ }^{67}$ When the second endoscopic therapy fails, TAE or surgery should be considered.
3. Relook endoscopy: routine second-look endoscopy is not recommended, as it is cost ineffective. Second-look endoscopy is indicated if there are signs of recurrent bleed or if initial hemostasis was not satisfactory. ${ }^{82}$ Prophylactic TAE is not indicated after successful endoscopic hemostasis even in the presence of high-risk stigmata of rebleed, as it is not cost-effective. ${ }^{83}$ EDP-guided hemostasis, although have shown less rebleeding rates, is not yet recommended in view of lack of high quality data. ${ }^{84}$ If second endoscopy fails to achieve hemostasis, then TAE and surgery should be considered. 


\section{Postendoscopy Management}

High dose IV PPI is recommended for initial 72 hours to prevent recurrent bleed if high-risk stigmata (Forrest's class IA, IB, IIA, and IIb) is observed during endoscopy. In case of no high-risk stigmata (Forrest's IIC and III), patient can be discharged on once daily PPI. ${ }^{85}$ If Helicobacter pylori is positive during index endoscopy, anti-H. pylori, therapy based on local resistance pattern should be prescribed and eradication should be documented. ${ }^{86}$ If $H$. pylori is negative at index endoscopy, repeat testing at 4 weeks is warranted as sensitivity of detection of $H$. pylori decreases in the presence of bleed. ${ }^{87}$ Antiplatelets can be resumed within 3 to 5 days and anticoagulants can be resumed within 7 days, if indicated, after consultation with a cardiologist. ${ }^{88}$ DOAC can be considered in this context in view of its rapid onset of action and better safety profile. If $H$. pylori is negative and antithrombotics need to be continued, then cotherapy with PPI is indicated to prevent recurrent bleed. . $^{27,89}$

\section{Strategy for Resource Limited Countries}

Studies from resource-limited countries, such as Tanzania and Nigeria, have shown that $50 \%$ of the patients with UGIB having severe anemia did not receive blood transfusion while one-third to one-fourth of the cases could not be offered endotherapy. ${ }^{90,91}$ These studies suggest that immediate resuscitation, restrictive transfusion strategy, and early EGD may be cost-effective options. Use of prognostic scoring systems can help exclude low-risk patients from unnecessary hospital admissions. Preemptive PPI use may be a cost-effective strategy to reduce endotherapy need. ${ }^{92}$ Endoscopic thermal and injection therapy are cost-effective conventional techniques. OTSC has been found to be a cost-effective strategy for recurrent bleed. ${ }^{93}$

\section{Conclusion}

Management of patients presenting with NVUGIH encompasses a multidisciplinary team approach to triage and stabilize the patient on presentation to the hospital. Endoscopy should be performed within 12 to 24 hours of presentation. Multiple modalities, both conventional and newer modalities, are available and a combination of these techniques can be used to optimize endotherapy. Persistent and recurrent bleed can be tackled using newer modalities. The various modalities have their specific techniques, advantages and efficacy levels and are to be used in accordance to the availability of the technique, expertise, and the patient and lesion-related factors to get the best outcome.

\section{Authors' Contributions}

C.L.B.: conception and design, review of literature, data analysis, drafting the work, and final approval.

A.K.: review of literature, data analysis, drafting the work, and final approval.

J.S.: conception and design, data interpretation, intellectual review of the work, and final approval.
All the authors have approved the final version of the work.

Funding

None.

Conflict of Interest

None declared.

\section{References}

1 Stanley AJ, Laine L. Management of acute upper gastrointestinal bleeding. BMJ 2019;364:1536

2 Blatchford O, Murray WR, Blatchford M. A risk score to predict need for treatment for upper-gastrointestinal haemorrhage. Lancet 2000;356(9238):1318-1321

3 Rockall TA, Logan RF, Devlin HB, Northfield TC. Risk assessment after acute upper gastrointestinal haemorrhage. Gut 1996;38(3):316-321

4 Saltzman JR, Tabak YP, Hyett BH, Sun X, Travis AC, Johannes RS. A simple risk score accurately predicts in-hospital mortality, length of stay, and cost in acute upper GI bleeding. Gastrointest Endosc 2011;74(6):1215-1224

5 Baradarian R, Ramdhaney S, Chapalamadugu R, et al. Early intensive resuscitation of patients with upper gastrointestinal bleeding decreases mortality. Am J Gastroenterol 2004;99(4):619-622

6 Binmoeller KF, Thonke F, Soehendra N. Endoscopic hemoclip treatment for gastrointestinal bleeding. Endoscopy 1993;25(2):167-170

7 Naseer M, Lambert K, Hamed A, Ali E. Endoscopic advances in the management of non-variceal upper gastrointestinal bleeding: A review. World J Gastrointest Endosc 2020;12(1):1-16

8 Banerjee A, Bishnu S, Dhali GK. Acute upper gastrointestinal bleed: An audit of the causes and outcomes from a tertiary care center in eastern India. Indian J Gastroenterol 2019;38(3):190-202

9 Mathew P, Kanni PY, Gowda M, et al. Retrospective study of clinical profile, endoscopic profile and in hospital mortality in acute upper gastrointestinal bleeding in tertiary care centre in South India. International Journal of Contemporary Medical Research 2019;6(8):H1-H5

10 Sourabh S, Sharma N, Sharma R, et al. Clinical profile, severity and outcome of acute upper gastrointestinal bleeding in elderly patients compared to non-elderly patients: a prospective observational study. J Assoc Physicians India 2019;67(9):30-32

11 Abougergi MS, Travis AC, Saltzman JR. The in-hospital mortality rate for upper GI hemorrhage has decreased over 2 decades in the United States: a nationwide analysis. Gastrointest Endosc 2015;81(4):882-8.e1

12 Taefi A, Cho WK, Nouraie M. Decreasing trend of upper gastrointestinal bleeding mortality risk over three decades. Dig Dis Sci 2013;58(10):2940-2948

13 Laine L, Yang H, Chang SC, Datto C. Trends for incidence of hospitalization and death due to GI complications in the United States from 2001 to 2009. Am J Gastroenterol 2012;107(8):1190-1195, quiz 1196

14 Wuerth BA, Rockey DC. Changing epidemiology of upper gastrointestinal hemorrhage in the last decade: a nationwide analysis. Dig Dis Sci 2018;63(5):1286-1293

15 Loperfido S, Baldo V, Piovesana E, et al. Changing trends in acute upper-GI bleeding: a population-based study. Gastrointest Endosc 2009;70(2):212-224

16 Ramaekers R, Mukarram M, Smith CA, Thiruganasambandamoorthy V. The predictive value of preendoscopic risk scores to predict adverse outcomes in emergency 
department patients with upper gastrointestinal bleeding: a systematic review. Acad Emerg Med 2016;23(11):1218-1227

17 Stanley AJ, Laine L, Dalton HR, et al. International Gastrointestinal Bleeding Consortium. Comparison of risk scoring systems for patients presenting with upper gastrointestinal bleeding: international multicentre prospective study. BMJ 2017;356:i6432

18 Villanueva C, Colomo A, Bosch A, et al. Transfusion strategies for acute upper gastrointestinal bleeding. $N$ Engl J Med 2013;368(1):11-21

19 Derogar M, Sandblom G, Lundell L, et al. Discontinuation of low-dose aspirin therapy after peptic ulcer bleeding increases risk of death and acute cardiovascular events. Clin Gastroenterol Hepatol 2013;11(1):38-42

20 Wang XX, Dong B, Hong B, et al. Long-term prognosis in patients continuing taking antithrombotics after peptic ulcer bleeding. World J Gastroenterol 2017;23(4):723-729

21 Barkun AN, Almadi M, Kuipers EJ, et al. Management of nonvariceal upper gastrointestinal bleeding: guideline recommendations from the International Consensus Group. Ann Intern Med 2019;171(11):805-822

22 Fujishiro M, Iguchi M, Kakushima N, et al. Guidelines for endoscopic management of non-variceal upper gastrointestinal bleeding. Dig Endosc 2016;28(4):363-378

23 Mujtaba S, Chawla S, Massaad JF. Diagnosis and management of non-variceal gastrointestinal hemorrhage: a review of current guidelines and future perspectives. J Clin Med 2020;9(2):402

24 Karstensen JG, Ebigbo A, Aabakken L, et al. Nonvariceal upper gastrointestinal hemorrhage: European Society of Gastrointestinal Endoscopy (ESGE) cascade guideline. Endosc Int Open 2018;6(10):E1256-E1263

25 Gralnek IM, Stanley AJ, Morris AJ, et al. Endoscopic diagnosis and management of nonvariceal upper gastrointestinal hemorrhage (NVUGIH): European Society of Gastrointestinal Endoscopy (ESGE) Guideline - Update 2021. Endoscopy 2021;53(3):300-332

26 Mullady DK, Wang AY, Waschke KA. AGA clinical practice update on endoscopic therapies for non-variceal upper gastrointestinal bleeding: expert review. Gastroenterology 2020;159(3):1120-1128

27 Sostres C, Marcén B, Laredo V, et al. Risk of rebleeding, vascular events and death after gastrointestinal bleeding in anticoagulant and/or antiplatelet users. Aliment Pharmacol Ther 2019;50(8):919-929

28 Sreedharan A, Martin J, Leontiadis GI, et al. Proton pump inhibitor treatment initiated prior to endoscopic diagnosis in upper gastrointestinal bleeding. Cochrane Database Syst Rev 2010;20102010(7):CD005415

29 Sung JJ, Chiu PW, Chan FKL, et al. Asia-Pacific working group consensus on non-variceal upper gastrointestinal bleeding: an update 2018. Gut 2018;67(10):1757-1768

30 Riha HM, Wilkinson R, Twilla J, et al. Octreotide added to a proton pump inhibitor versus a proton pump inhibitor alone in nonvariceal upper-gastrointestinal bleeds. Ann Pharmacother 2019;53(8):794-800

31 HALT-IT Trial Collaborators. Effects of a high-dose 24-h infusion of tranexamic acid on death and thromboembolic events in patients with acute gastrointestinal bleeding (HALT-IT): an international randomised, double-blind, placebo-controlled trial. Lancet 2020;395(10241) :1927-1936

32 Bai Y, Guo JF, Li ZS. Meta-analysis: erythromycin before endoscopy for acute upper gastrointestinal bleeding. Aliment Pharmacol Ther 2011;34(2):166-171

33 Kessel B, Olsha O, Younis A, Daskal Y, Granovsky E, Alfici R. Evaluation of nasogastric tubes to enable differentiation between upper and lower gastrointestinal bleeding in unselected patients with melena. Eur J Emerg Med 2016;23(1):71-73
34 Chaudhuri D, Bishay K, Tandon P, et al. Prophylactic endotracheal intubation in critically ill patients with upper gastrointestinal bleed: a systematic review and meta-analysis. JGH Open 2019;4(1):22-28

35 Lau JYW, Yu Y, Tang RSY, et al. Timing of endoscopy for acute upper gastrointestinal bleeding. $\mathrm{N}$ Engl J Med 2020;382(14):1299-1308

36 Garg SK, Anugwom C, Campbell J, et al. Early esophagogastroduodenoscopy is associated with better outcomes in upper gastrointestinal bleeding: a nationwide study. Endosc Int Open 2017;5(5):E376-E386

37 Siau K, Hodson J, Ingram R, et al. Time to endoscopy for acute upper gastrointestinal bleeding: Results from a prospective multicentre trainee-led audit. United European Gastroenterol J 2019;7(2):199-209

38 Jeong N, Kim KS, Jung YS, Kim T, Shin SM. Delayed endoscopy is associated with increased mortality in upper gastrointestinal hemorrhage. Am J Emerg Med 2019;37(2):277-280

39 Forrest JA, Finlayson ND, Shearman DJ. Endoscopy in gastrointestinal bleeding. Lancet 1974;2(7877) :394-397

40 Jensen DM, Eklund S, Persson T, et al. Reassessment of rebleeding risk of Forrest IB (Oozing) peptic ulcer bleeding in a large international randomized trial. Am J Gastroenterol 2017;112(3):441-446

41 Elmunzer BJ, Young SD, Inadomi JM, Schoenfeld P, Laine L. Systematic review of the predictors of recurrent hemorrhage after endoscopic hemostatic therapy for bleeding peptic ulcers. Am J Gastroenterol 2008;103(10):2625-2632, quiz 2633

42 Sung JJ, Tsoi KK, Lai LH, Wu JC, Lau JY. Endoscopic clipping versus injection and thermo-coagulation in the treatment of non-variceal upper gastrointestinal bleeding: a meta-analysis. Gut 2007;56(10):1364-1373

43 Marmo R, Rotondano G, Piscopo R, Bianco MA, D’Angella R, Cipolletta L. Dual therapy versus monotherapy in the endoscopic treatment of high-risk bleeding ulcers: a meta-analysis of controlled trials. Am J Gastroenterol 2007;102(2):279-289, quiz 469

44 Calvet X, Vergara M, Brullet E, Gisbert JP, Campo R. Addition of a second endoscopic treatment following epinephrine injection improves outcome in high-risk bleeding ulcers. Gastroenterology 2004;126(2):441-450

45 Vergara M, Bennett C, Calvet X, Gisbert JP. Epinephrine injection versus epinephrine injection and a second endoscopic method in high-risk bleeding ulcers. Cochrane Database Syst Rev 2014;(10):CD005584

46 Saltzman JR, Strate LL, Di Sena V, et al. Prospective trial of endoscopic clips versus combination therapy in upper GI bleeding (PROTECCT-UGI bleeding. Am J Gastroenterol 2005;100(7):1503-1508

47 Lin HJ, Perng CL, Sun IC, Tseng GY. Endoscopic haemoclip versus heater probe thermocoagulation plus hypertonic saline-epinephrine injection for peptic ulcer bleeding. Dig Liver Dis 2003;35(12):898-902

48 Parsi MA, Schulman AR, Aslanian HR, et al; ASGE technology committee; ASGE Technology Committee Chair. Devices for endoscopic hemostasis of nonvariceal GI bleeding (with videos. VideoGIE 2019;4(7):285-299

49 Wang TJ, Aihara H, Thompson AC, Schulman AR, Thompson CC, Ryou M. Choosing the right through-the-scope clip: a rigorous comparison of rotatability, whip, open/close precision, and closure strength (with videos. Gastrointest Endosc 2019;89(1):77-86.e1

50 Cipolletta L, Bianco MA, Marmo R, et al. Endoclips versus heater probe in preventing early recurrent bleeding from peptic ulcer: a prospective and randomized trial. Gastrointest Endosc 2001;53(2):147-151 
51 Lin HJ, Hsieh YH, Tseng GY, Perng CL, Chang FY, Lee SD. A prospective, randomized trial of endoscopic hemoclip versus heater probe thermocoagulation for peptic ulcer bleeding. Am J Gastroenterol 2002;97(9):2250-2254

52 Peng YC, Chen SW, Tung CF, Chow WK, Ho SP, Chang CS. Comparison the efficacy of intermediate dose argon plasma coagulation versus hemoclip for upper gastrointestinal non-variceal bleeding. Hepatogastroenterology 2013;60(128):2004-2010

53 García-Iglesias P, Villoria A, Suarez D, et al. Meta-analysis: predictors of rebleeding after endoscopic treatment for bleeding peptic ulcer. Aliment Pharmacol Ther 2011;34(8):888-900

54 Kim JW, Jang JY, Lee CK, Shim JJ, Chang YW. Comparison of hemostatic forceps with soft coagulation versus argon plasma coagulation for bleeding peptic ulcer-a randomized trial. Endoscopy 2015;47(8):680-687

55 Nunoue T, Takenaka R, Hori K, et al. A randomized trial of monopolar soft-mode coagulation versus heater probe thermocoagulation for peptic ulcer bleeding. J Clin Gastroenterol 2015;49(6):472-476

56 Arima S, Sakata Y, Ogata S, et al. Evaluation of hemostasis with soft coagulation using endoscopic hemostatic forceps in comparison with metallic hemoclips for bleeding gastric ulcers: a prospective, randomized trial. J Gastroenterol 2010;45(5):501-505

57 Kataoka M, Kawai T, Hayama Y, et al. Comparison of hemostasis using bipolar hemostatic forceps with hemostasis by endoscopic hemoclipping for nonvariceal upper gastrointestinal bleeding in a prospective non-randomized trial. Surg Endosc 2013;27(8):3035-3038

58 Richter-Schrag HJ, Glatz T, Walker C, Fischer A, Thimme R. First-line endoscopic treatment with over-the-scope clips significantly improves the primary failure and rebleeding rates in high-risk gastrointestinal bleeding: A single-center experience with 100 cases. World J Gastroenterol 2016;22(41):9162-9171

59 Wedi E, Fischer A, Hochberger J, Jung C, Orkut S, Richter-Schrag HJ. Multicenter evaluation of first-line endoscopic treatment with the OTSC in acute non-variceal upper gastrointestinal bleeding and comparison with the Rockall cohort: the FLETRock study. Surg Endosc 2018;32(1):307-314

60 Chandrasekar VT, Desai M, Aziz M, et al. Efficacy and safety of over-the-scope clips for gastrointestinal bleeding: a systematic review and meta-analysis. Endoscopy 2019;51(10):941-949

61 Gölder S, Neuhas L, Freuer D, et al. Over-the-scope clip in peptic ulcer bleeding: clinical success in primary and secondary treatment and factors associated with treatment failure. Endosc Int Open 2019;7(6):E846-E854

62 Jensen DM, Kovacs T, Ghassemi KA, Kaneshiro M, Gornbein J. Randomized controlled trial of over-the-scope clip as initial treatment of severe nonvariceal upper gastrointestinal bleeding. Clin Gastroenterol Hepatol 2020;(e-pub ahead of print). doi:10.1016/j.cgh.2020.08.046

63 Schmidt A, Gölder S, Goetz M, et al. Over-the-scope clips are more effective than standard endoscopic therapy for patients with recurrent bleeding of peptic ulcers. Gastroenterology 2018;155(3):674-686.e6

64 Brandler J, Baruah A, Zeb M, et al. Efficacy of over-the-scope clips in management of high-risk gastrointestinal bleeding. Clin Gastroenterol Hepatol 2018;16(5):690-696.e1

65 Haddara S, Jacques J, Lecleire S, et al. A novel hemostatic powder for upper gastrointestinal bleeding: a multicenter study (the "GRAPHE" registry. Endoscopy 2016;48(12):1084-1095

66 Chen YI, Barkun A, Nolan S. Hemostatic powder TC-325 in the management of upper and lower gastrointestinal bleeding: a two-year experience at a single institution. Endoscopy 2015;47(2):167-171

67 Prei JC, Barmeyer C, Bürgel N, et al. EndoClot polysaccharide hemostatic system in nonvariceal gastrointestinal bleeding: results of a prospective multicenter observational pilot study. J Clin Gastroenterol 2016;50(10):e95-e100

68 Park JS, Kim HK, Shin YW, Kwon KS, Lee DH. Novel hemostatic adhesive powder for nonvariceal upper gastrointestinal bleeding. Endosc Int Open 2019;7(12):E1763-E1767

69 Alzoubaidi D, Hussein M, Rusu R, et al. Outcomes from an international multicenter registry of patients with acute gastrointestinal bleeding undergoing endoscopic treatment with Hemospray. Dig Endosc 2020;32(1):96-105

70 Baracat FI, de Moura DTH, Brunaldi VO, et al. Randomized controlled trial of hemostatic powder versus endoscopic clipping for non-variceal upper gastrointestinal bleeding. Surg Endosc 2020;34(1):317-324

71 Prasad VGM, Prasad M, Asif SM, et al. Endoscopic collagen spray- a novel method which can be used as an adjunct to conventional hemostatic techniques in peptic ulcer bleeding. J Clin Gastroenterol Hepatol 2018;2(1doi:10.21767/2575-7733.1000030

72 Agarwal A, Benias P, Brewer Gutierrez OI, et al. Endoscopic suturing for management of peptic ulcer-related upper gastrointestinal bleeding: a preliminary experience. Endosc Int Open 2018;6(12):E1439-E1444

73 Barola S, Fayad L, Hill C, et al. Endoscopic management of recalcitrant marginal ulcers by covering the ulcer bed. Obes Surg 2018;28(8):2252-2260

74 Levy MJ, Wong Kee Song LM, Farnell MB, Misra S, Sarr MG, Gostout CJ. Endoscopic ultrasound (EUS)-guided angiotherapy of refractory gastrointestinal bleeding. Am J Gastroenterol 2008;103(2):352-359

75 García de la Filia I, Hernanz N, Vázquez Sequeiros E, Tavío Hernández E. Recurrent gastrointestinal bleeding secondary to Dieulafoy's lesion successfully treated with endoscopic ultrasound-guided sclerosis. Gastroenterol Hepatol 2018;41(5):319-320

76 Kantowski M, Schoepfer AM, Settmacher U, Stallmach A, Schmidt C. Assessment of endoscopic Doppler to guide hemostasis in high risk peptic ulcer bleeding. Scand J Gastroenterol 2018;53(10-11):1311-1318

77 Jensen DM, Kovacs TOG, Ohning GV, et al. Doppler endoscopic probe monitoring of blood flow improves risk stratification and outcomes of patients with severe nonvariceal upper gastrointestinal hemorrhage. Gastroenterology 2017;152(6):13101318.e1

78 Sverdén E, Mattsson F, Lindström D, Sondén A, Lu Y, Lagergren J. Transcatheter arterial embolization compared with surgery for uncontrolled peptic ulcer bleeding: a population-based cohort study. Ann Surg 2019;269(2):304-309

79 Kyaw M, Tse Y, Ang D, Ang TL, Lau J. Embolization versus surgery for peptic ulcer bleeding after failed endoscopic hemostasis: a meta-analysis. Endosc Int Open 2014;2(1):E6-E14

80 Lau JY, Sung JJ, Lam YH, et al. Endoscopic retreatment compared with surgery in patients with recurrent bleeding after initial endoscopic control of bleeding ulcers. N Engl J Med 1999;340(10):751-756

81 Grassia R, Capone P, Iiritano E, et al. Non-variceal upper gastrointestinal bleeding: rescue treatment with a modified cyanoacrylate. World J Gastroenterol 2016;22(48):10609-10616

82 Park SJ, Park H, Lee YC, et al. Effect of scheduled second-look endoscopy on peptic ulcer bleeding: a prospective randomized multicenter trial. Gastrointest Endosc 2018;87(2):457-465

83 Lau JYW, Pittayanon R, Wong KT, et al. Prophylactic angiographic embolisation after endoscopic control of bleeding to high-risk peptic ulcers: a randomised controlled trial. Gut 2019;68(5):796-803

84 Jensen DM, Ohning GV, Kovacs TO, et al. Doppler endoscopic probe as a guide to risk stratification and definitive hemostasis of peptic ulcer bleeding. Gastrointest Endosc 2016;83(1):129-136 
85 Sachar H, Vaidya K, Laine L. Intermittent vs continuous proton pump inhibitor therapy for high-risk bleeding ulcers: a systematic review and meta-analysis. JAMA Intern Med 2014;174(11):1755-1762

86 Gisbert JP, Khorrami S, Carballo F, Calvet X, Gene E, Dominguez-Muñoz E. Meta-analysis: Helicobacter pylori eradication therapy vs. antisecretory non-eradication therapy for the prevention of recurrent bleeding from peptic ulcer. Aliment Pharmacol Ther 2004;19(6):617-629

87 Gisbert JP, Abraira V. Accuracy of Helicobacter pylori diagnostic tests in patients with bleeding peptic ulcer: a systematic review and meta-analysis. Am J Gastroenterol 2006;101(4):848-863

88 Kido K, Scalese MJ. Management of oral anticoagulation therapy after gastrointestinal bleeding: whether to, when to, and how to restart an anticoagulation therapy. Ann Pharmacother 2017;51(11):1000-1007

89 Moayyedi P, Eikelboom JW, Bosch J, et al. COMPASS Investigators. Pantoprazole to prevent gastroduodenal events in patients receiving rivaroxaban and/or aspirin in a randomized, double-blind, placebo-controlled trial. Gastroenterology 2019;157(2):403-412.e5

90 Rajan SS, Sawe HR, Iyullu AJ, et al. Profile and outcome of patients with upper gastrointestinal bleeding presenting to urban emergency departments of tertiary hospitals in Tanzania. BMC Gastroenterol 2019;19(1):212

91 Alatise OI, Aderibigbe AS, Adisa AO, Adekanle O, Agbakwuru AE, Arigbabu AO. Management of overt upper gastrointestinal bleeding in a low resource setting: a real world report from Nigeria. BMC Gastroenterol 2014;14:210

92 Tsoi KK, Lau JY, Sung JJ. Cost-effectiveness analysis of highdose omeprazole infusion before endoscopy for patients with upper-GI bleeding. Gastrointest Endosc 2008;67(7):1056-1063

93 Kuellmer A, Behn J, Meier B, et al. Over-the-scope clips are cost-effective in recurrent peptic ulcer bleeding. United European Gastroenterol J 2019;7(9):1226-1233 